\title{
How Concentrated are Global Infrastructure Markets?
}

\author{
Daniel Benitez \\ Université des Sciences Sociales \\ Toulouse I \\ daniel.benitez@univ-tlse1.fr
}

Antonio Estache

World Bank and

ECARES, Université Libre de Bruxelles

aestache@worldbank.org

\begin{abstract}
In infrastructure, the possibility of a positive relationship between operators' profitability and the degree of concentration is a major political issue in view of the wide diversity of feelings about the potential role of the private sector. This is particularly important in view of (i) the large residual degree of monopolies, (ii) the protection they are granted through exclusivity clauses built in service delivery contracts and (iii) the widespread sense that the same operators tend to be present in most of the privatized operations. The main purpose of this paper is to provide a first set of quantitative assessments of the degree of concentration in infrastructure at the global and at the regional level. Concentration issues were identified in only about $20 \%$ of the cases studied, a presumption of concentration was found in another $30 \%$ of the cases. We find no correlation between the degree of concentration and the degree of reform adopted by a region or a sector. In more general terms, we find no scope for simple encompassing regional or sectoral statements because issues are region- and sector-specific. We conclude by arguing that there are a few cases and regions in which it would make sense for a supranational competition or regulation agency to ensure that the interests of the users are protected more effectively against the risks of collusion and other types of anti-competitive behaviors local regulators would not be equipped to address.
\end{abstract}

\section{World Bank Policy Research Working Paper 3513, February 2005}

The Policy Research Working Paper Series disseminates the findings of work in progress to encourage the exchange of ideas about development issues. An objective of the series is to get the findings out quickly, even if the presentations are less than fully polished. The papers carry the names of the authors and should be cited accordingly. The findings, interpretations, and conclusions expressed in this paper are entirely those of the authors. They do not necessarily represent the view of the World Bank, its Executive Directors, or the countries they represent. Policy Research Working Papers are available online at http:/lecon.worldbank.org.

We are particularly grateful to Marcelo Celani, Claude Crampes, Mathias Dewatripont, Jose-Luis Guasch, Anne Perrot, Russell Pittman, Richard Schlirf, Tomas Serebrisky, Chris Snyder and Lourdes Trujillo for useful conceptual discussions and suggestions in the (slow) preparation of this note. 


\section{Introduction}

The promotion of competition in the delivery of infrastructure services was to be one of the main expected contributions of the reforms of the 1990s throughout the world. Depending on the sector, roughly $40 \%$ (water) to $70 \%$ (telecoms) of the developing and transition countries introduced some major institutional reform to ease competition in or for the market. ${ }^{1}$ This search for competition resulted in major structural changes in infrastructure in many countries. Unbundling of the various segments of each sub-sector was the expected norm of many reforms. For instance, in electricity, generation, transmission and distribution, operations became separate business units in many countries and in telecoms, fixed and mobile started to be handled as commercially distinct activities. These changes were all intended to increase the number of actors in infrastructure service delivery.

Because of economies of scale and scope and, in many developing countries because of the high commercial risks faced by private operators, limits to the achievable degree of competition in the market continued to prevail in some cases. In small countries, monopolies are indeed hard to avoid in water and energy distribution and in bigger countries, national monopolies are replaced by regional or local monopolies, but monopolies nonetheless. This is why competition for the market has become so popular during the 1990s. Residual monopolies were auctioned --rather than awarded through beauty contests or negotiations-because auction theory promised to deliver many of the gains that competition in the market would have delivered.

One of the assumptions implicit in this promise was that the number of potential providers in the sector would be large enough to allow competition for the market to be effective. This did not happen for all sectors. In Latin America, during the 1990s, 92\% of the water and sanitation auctions, $76 \%$ of the transport auctions and $57 \%$ of the energy auctions awarded had 3 or fewer bidders (Estache (2003)). The only sector with many bidders was the telecoms sector. For some sectors, the anecdotal evidence suggests that competition was limited simply because the number of actors was limited. The most extreme is the water sector. Estache and Trujillo (2004) report that between 1990 and 1997 out of the 58 large water and sewerage projects signed in developing countries, over $50 \%$ were awarded to the

\footnotetext{
${ }^{1}$ Estache and Goicoechea (2004)
} 
same firm and $40 \%$ to two others. In most infrastructure sectors, the limitation of the competition also reflects the fact that many of the players tend to hedge by investing as members of consortia rather than as individual providers. This is quite relevant, not only to the assessment of the degree of competition but also from the viewpoint of the assessment of the sectors' concentration. It also means that the estimation of the extent of concentration does indeed require a knowledge of the composition of the ownership of each large operator-and ideally, its change over time.

Why should we care? Because in infrastructure the possibility of a positive relationship between operators' profitability and the degree of concentration is a major political issue--in view of the wide diversity of views on the potential role of the private sector. The concern about a negative relationship between the profitability of privatized infrastructure services delivered by monopolies and social performance underpins the theory of regulation today. This concern is reinforced by the fact that the products covered here tend to be homogeneous (water, electricity, telecoms) and that reform processes often reinforced the residual monopolies by protecting them with exclusivity clauses. This is why the reforms in so many cases had to include the creation of an independent regulatory agency. Unfortunately, local regulators do not enjoy supranational evidence on what could make the service they are auctioning not competitive. Nor do they have a mandate to assess it.

The general common wisdom is that the more concentrated the market, the more the behavior of that market's operators will be harmful to social well-being because they will try to raise prices to obtain higher profits. ${ }^{2}$ Moreover, given the decreasing nature of the demand function, a policy of high prices restricts supply, a major issue in any country or region in which one of the main expected outcomes of reform is to speed up connection and access rates-besides the economic opportunity cost associated with the lower supply. ${ }^{3}$

In addition to these traditional concerns, the modern theory of industrial organization suggests that even in the absence of a single dominant firm in a region, competition in the sector could also be threatened in situations of tacit collusion in market structures similar to

\footnotetext{
${ }^{2}$ This view is known as the Structure-Conduct-Performance Paradigm. It has dominated industrial organization for about 50 years before being questioned by a vision of the field which tends to prefer the study of strategic behavior on a case by case over the search for broad regularities. See Pepall, Richards and Norman (2002), for instance for a good textbook discussion.

${ }^{3}$ Several objections can be made to the common wisdom of a negative relationship between concentration and well-being. Most relevant here may be that demand may increase with quality, and if a large company is likely to offer better quality of service than smaller ones (regularity of service for example), a higher price does not necessarily mean a restriction of the quantity sold.
} 
those prevailing in the regional or global infrastructure markets. In other words, there is a risk that operators delivering services in the same sector across countries could engage in coordination with outcomes in terms of prices or quantities, equivalent to those prevailing under a cartel. ${ }^{4}$

With this background in mind, the main purpose of this paper is twofold. First, we provide quantitative indicators on the residual degree of concentration in each sub sector after a decade of reforms across sectors and across regions. We cover electricity generation and distribution, fixed and mobile telephony, water and sanitation. Second, we discuss the extent to which there may be a case for more coordination between country specific agencies or even a case for a supra-national agency to address any concern for excessive concentration in a sector.

To conduct the assessment, we built the database from scratch from the partial information available on the web, mostly from international agencies specialized in some sectors (i.e. International Energy Agency, Water and Sanitation Program of the World Bank or the International Telecommunication Union) and from specialized consulting and credit rating firms. Because the database does not cover the full supply spectrum, we also had to approximate the concentration indices typically used by competition agencies. The approximation provides a range for the market power rather than the point estimate typically relied on by competition authorities to take decisions. Accordingly, we propose an adjusted associated rule to assess market power. The results seem however to be robust enough to identify the sector and regions in which a case for a supranational competition authority or coordinated regulation could be made.

The rest of the paper is organized as follows. Section 2 presents the methodology used to approximate the degree of concentration in each market and each region of the world. Section 3 presents the results. Section 4 discusses some of the policy implications. Section 5 concludes.

\footnotetext{
${ }^{4}$ See for instance Pepall, Richards and Norman (2002), pp349-405
} 


\section{The methodology}

To assess the extent to which global infrastructure markets are concentrated and enjoy market power at the regional or global level, information is needed on the number of firms active in the market, their relative size in that market and their ownership structure. The section first sorts out the conceptual issues associated with the characterization of the relevant firms, owners and definition of a market. Next, it discusses the practical challenges associated with the quantification of market power and the solutions adopted in this paper.

\subsection{Some conceptual background}

From the perspective of competition policy, the first issue to address is the characterization of the firms, in particular in terms of their size. It should ideally be measured by the annual flow of sales in the relevant market or, if the products are homogeneous, by the quantities sold (since the price is the same for all firms) or also by the physical capacity of the operators. In practice, the appropriate data is not always available and it is sometime easier to approximate the size by the populations covered by the providers.

The second challenge is the definition of the relevant market. Under modern competition law, it is defined along two dimensions: the product and the geographical dimensions. The objective is to identify the market in which firms can limit competition of the industry under review. The reference market of an industry thus is the set of products and points of sale from which demand cannot escape a specific operator and hence one in which this operator could impose a "small but significant and non-transitory increase" in price-as defined in the US legislation for instance.

The geographical reference market consists of the area in which the firms concerned are involved in the supply of products or services with little or no competition. By design, in most countries, the perceived reference market tends to be a local or national monopoly. This is why the local lack of competition in infrastructure services at the local or national level is typically handled by an independent regulatory capacity in most reforming countries.

What happens when a single operator or a small set of operators controls de facto regional or global markets? This is not an issue expected to be addressed by the local regulators. However, it does raise a public policy concern since users have much less choice when an auction cannot guarantee an efficient outcome. This is the case when a collusive 
behavior reduces competition at the regional level, even if it is unnoticed at the local level. In this case, it could be argued that the relevant market for infrastructure services with at least some degree of restriction to competition across countries is a supranational regional market (e.g. Latin America, Africa or Asia). In some instances, when the sector is controlled by a limited number of specialized firms and there is a concern for world wide collusion, the relevant market may actually be the global market.

\subsection{Towards a specific measure of global or regional market power}

The main measure of market power relies on simple statistical observations, essentially market shares, and combines them into concentration indices from which risks of abuse are assessed. This section describes the approach followed here to assess regional and global concentration level after a brief reminder on the mechanics of the main indices used in practice--assuming for now that the issue of defining the relevant market has been settled. ${ }^{5}$

If $q_{i}$ is the production of firm $i$ and $n$ the number of firms active in the relevant market — national or supranational—, the market share of $i$ is measured by:

$$
s_{i}=\frac{q_{i}}{\sum_{j=1}^{n} q_{j}}
$$

The minimum market share of a firm in the relevant market is higher than $0 \%$ and the maximum is $100 \%$, that is $0<s_{i} \leq 1$.In the context of this paper, the shares are defined in terms of the share of ownership in a specific license or concession contract, rather tan in terms of the incorporated operators to which the contract was awarded. In other words, if an contract is owned in equal proportions by two operators, each operator $i$ only gets credited with $50 \%$ of ownership in the in the calculation of its $s_{i .}$.

In practice, many firms publish their activities per country and the share in their total business as part of their annual report. Based on that information, if a firm share is $\alpha$-percent in a specific contract in a specific country, we compute the $\alpha$-percent of the MWs installed, customers covered or lines depending on the industry considered. In other words, if a contract is owned in equal proportions by two operators, each operator $i$ only gets credited with $50 \%$

\footnotetext{
${ }^{5}$ For a longer discussion see for instance Martin (1993) pp164-209
} 
of ownership in the in the calculation of its $s_{i . .}$. This approach means that we control for ownership, independently of whether the firm in the sample has the control or not. Assuming full ownership (100\%) may leads to an overestimation when more than one firm in the sample holds shares of the same provider i.e. in Argentina, Ondeo and Veolia have shares in Aguas Argentinas. See the appendix for a more detailed explanation.

Knowing the shares $\left(s_{1}, s_{2}, \ldots, s_{n}\right)$, the challenge is to construct an index that can provide information about regional or global market concentration simply and rapidly. There are essentially two groups of indices meeting that challenge: composite (or global) or partial indices.

The most familiar member of the global indices is the Herfindahl-Hirschman Index (HHI), defined by

$$
H H I=10^{4} \sum_{i=1}^{n} s_{i}^{2}
$$

For each exogenous value of the number of active firms $n$, this index varies between a minimum of $\frac{10^{4}}{n}$ when all firms are equal $\left(s_{i}=\frac{1}{n}\right)$ and a maximum of $10^{4}$ when there is one very large firm (nearly monopolistic) with $n-1$ very small competitors. ${ }^{6}$ Markets with an HHI under 1000 are considered "not concentrated" and generally do not require further analysis. Market in which $1000<H H I<1800$ are "moderately concentrated" and competition is thought threatened if the merger causes the HHI to increase by more than 100 points. Finally, if the HHI exceeds 1800 , the market is highly concentrated and any transaction that causes an increase of $\triangle H H I>50$ calls for further inquiry.

These thresholds seem arbitrary, but they can be explained by considering that since $H H I=\frac{10^{4}}{n}$ when the $n$ firms are of the same size, the reciprocal value $\frac{10^{4}}{H H I}$ is a good indicator of the number of firms that play a central role in the market. This means that $\frac{10^{4}}{1000}=10$ firms present in a market define a relatively unconcentrated market, while $\frac{10^{4}}{1800}=5$ firms define a highly concentrated market.

\footnotetext{
${ }^{6}$ The index is discussed in the United States's Merger Guidelines as a possible filtering system to determine whether a planned merger should be cause for concern (Department of Justice and Federal Trade Commission Horizontal Merger Guidelines $§ 1.51$ (1992)) and an equivalent suggestion is available in European Law in Regulation EEC 4064/89.
} 
While this indicator is relatively easy to deal with in national markets, it is somewhat more complex to generate for supranational markets. None of the infrastructure sectors has an exhaustive database on operators or their activities around the world, including their share of ownership in various contracts. The big players are generally well known but they only represent a sub-set of the total number of actors. In that case, an alternative is to rely on a partial index which informs the competition agency with less than the desirable information set. A common such index is the sum of the market shares held by the $k$ largest firms (with $\mathrm{k}<\mathrm{n}$ where $\mathrm{n}$ is the total number of firms offering services in the sector). This is the $m$ seller concentration ratio:

$$
C R_{m}=\sum_{i=1}^{k} s_{i} \text { with } s_{1}>s_{2}>\ldots>s_{k}>s_{k+1}>\ldots>s_{n}
$$

For example, $C R_{4}$ measures the market share of the four largest firms. Such partial indices have a number of drawbacks. They provide very little information about differences between markets with a small number of firms. ${ }^{7}$

The main advantage of this partial index is its simplicity and its ease of interpretation. In addition, it can be used in an approximation of the relevant HHI. Indeed, Sleuwaegen and Dehandschutter (1986) have shown the existence of a non-linear relation between $H H I$ and $C R m$. In spite of a number of limitations, this results makes it easier to come up with a decision criteria in industries for which information is not available on all operators.

The approximation basically gives an upper and lower band for the $H H I$ corresponding to a given $C R$ :

$$
\begin{aligned}
H H_{\text {min }} & =\frac{C R m^{2}}{m} \\
H H_{\max } & =\left\{\begin{array}{cl}
C R m^{2} & \text { if } C R m \geq 1 / m \\
C R m / m & \text { otherwise }
\end{array}\right.
\end{aligned}
$$

This approximation has two problems. ${ }^{8}$ The first is that the relationship between HHI and $\mathrm{CR}$ is weaker the more concentrated the market is. Indeed, the spread between $\mathrm{HH}_{\min }$ and $\mathrm{HH}_{\max }$ increases with the concentration ratio. This problem can thus only be assessed ex-post

\footnotetext{
7 A second drawback is that, if mergers or acquisitions occur among firms not included among the four largest, and if those operations do not change the ranking of the top four firms, the $C_{4}$ index does not signal any change. This is more relevant when assessing the evolution of concentration than when taking a single snapshot.

${ }^{8}$ Note that we have to multiply by 10000 the lower and upper bound in the HH to get to the usual figure ranges
} 
once the concentration rate has been assessed. If it turns out that a few companies have a fairly high market share, the approximation is likely to be weak. The second is that it does not lead to the simple decision rule equivalent to the rule adopted by the US Department of Justice.

We suggest the following adaptation which could serve to any analyst interested in assessing supranational concentration rates:

(i) if both $\mathrm{HH}_{\min }$ and $\mathrm{HH}_{\max }$ are below 1000, there is no concentration problem;

(ii) if both $\mathrm{HH}_{\min }$ and $\mathrm{HH}_{\max }$ are over 1800, there is a clear case of concentration;

(iii) if $\mathrm{HH}_{\max }$ is above 1800 and $\mathrm{HH}_{\text {min }}$ between 1000 and 1800, the test is inconclusive but there are good reasons to be concerned with market power from concentration so the rule should read as inclusive but presumption that "yes there is concentration"

(iv) if $\mathrm{HH}_{\max }$ is between 1000 and 1800 and $\mathrm{HH}_{\min }$ below 1000, then the test is inconclusive but the presumption is that "no there is no concentration".

(v) if $\mathrm{HH}_{\max }$ is above 1800 and $\mathrm{HH}_{\min }$ below 1000, then the test is really inconclusive. ${ }^{9}$

\section{The sector specific assumptions and results}

This section briefly discusses the basic data and presents the results of the computation of the various maximum and minimum HHI indices. Most of the data is from 2003, unless otherwise specified. For every sector, we summarize the information. We report the market indicator selected, the minimum and maximum HHI computed, the number of operators covered by the indicator and their aggregate market share, the number of countries as well as the total number of contract or "cases" included in the database. The concentration index is computed for the main regional markets of the world as well as for the global market. Table 1 summarizes the information collected.

\footnotetext{
${ }^{9}$ Note that a large discrepancy between the lower and upper bound is not necessarily a signal of concentration.
} 
Table 1: Overview of the data available

\begin{tabular}{|c|c|c|c|c|c|c|}
\hline \multirow{2}{*}{ Sector } & \multicolumn{2}{|c|}{ Electricity } & \multicolumn{2}{|c|}{ Water \& Sanitation } & \multicolumn{2}{|c|}{ Telecommunication } \\
\hline & Generation & Distribution & Water & Sanitation & Fixed & Mobile \\
\hline Product Definition & $\begin{array}{c}\text { Installed capacity } \\
\text { (MWs) }\end{array}$ & $\begin{array}{c}\text { Number of customers } \\
\text { (connections) }\end{array}$ & \multicolumn{2}{|c|}{$\begin{array}{l}\text { Urban population covered }(*) \\
\text { 2. Country population }(* *)\end{array}$} & \multicolumn{2}{|c|}{$\begin{array}{c}\text { Number of working } \\
\text { lines }\end{array}$} \\
\hline Number of Players* & 16 firms & 12 firms & 7 firms & 7 firms & 9 firms & 9 firms \\
\hline \multicolumn{7}{|l|}{ Number of Countries in sample } \\
\hline OECD & 19 & 12 & 23 & 20 & 18 & 25 \\
\hline No OECD & 38 & 19 & 33 & 18 & 17 & 40 \\
\hline Total & 57 & 31 & 56 & 38 & 35 & 65 \\
\hline \multicolumn{7}{|l|}{ Market Shares: * } \\
\hline World & $18 \%$ & $31 \%$ & $23 \%(* *)-34 \%(*)$ & $23 \%(* *)-31 \%(*)$ & $39 \%$ & $37 \%$ \\
\hline
\end{tabular}

First it shows that we tried to report data on the sectors as unbundled as possible. Second, for the electricity and telecommunications, we managed to get market data close enough to what a competition agency would consider appropriate. For water and sanitation, we relied on two proxies: urban population and total population. The first probably gives a lower bound and the second an upper bound of the populations affected by the large operators covered by the database. We should thus get respectively a further level of upper and lower bound for the concentration index from these two measures. Third, the country coverage is relatively evenly distributed between OECD and non-OECD countries which ensures a reasonable sense of robustness when comparing the two country groups. Finally, the combination of the market shares and of the number of players suggests that there is no outrageous domination of any sector by a very limited number of actors and hence that the approximation method used here is unlikely to be very distorted at the global level.

At a more substantive level, a simple look at the line on the number of players suggests that for electricity and telecoms, the concentration issue is subject to debates since the number of firms is large enough according to the rule of thumb discussed earlier. For water and sanitation, the information on the number of firms already points to a fairly high concentration level. The rest of this section refines this first superficial assessment.

\subsection{Electricity}

For electricity, we differentiate between the two main activities: generation and distribution-i.e. local transmission and retailing; we did not find enough information on 
transmission. Generation tends to be competitive at the national level while distribution is not. We select a set of the main international actors according to the numbers of countries where these firms have activity but also with respect to the numbers of own MW installed for generation and customers covered for distribution. This choice is partially based on the information available from the Annual reports of the International Energy Agency and on information provided by credit rating agencies in their regular reports and information most commonly available on the web site of the main actors of the sector. In most of the cases, the database source for each firm is its own webpage.

Note that in generation we rely on installed capacity instead of on production to compute the HHI for two reasons. First, it captures the potential effect of concentration since a firm can produce up to capacity. ${ }^{10}$ Second, many firms do not publish production in their public reports and the sample size would have been much smaller.

\section{a. Electricity Generation}

For generation, we consider a set of 16 firms present in 57countries (19 OECD and 38 non OECD) and credited with $16 \%$ of the global market. The set of firms is composed of: American Electric Power (AEP), AES Corporation, CLP Group, Duke Energy, E.ON, Electricité de France (EDF), Electricidade de Portugal (EDP), ENDESA, ENTERGY, Union Fenosa (UF), Hong Kong Electric Group (HEG), Intergen, Public Service Enterprise Group (PSEG), Reliant Energy Inc., Southern Energy Company and Tractabel Power. ${ }^{11}$

At the global level, Table 2 generally confirms the expectations, although with a couple of surprises. Indeed, Table 2 shows that, as expected, this is not an overly concentrated market at least globally. In other words, generation is a competitive sector in general-although EDF and E.ON have a significantly larger market share than the others, their lead is not strong enough to distort competition in this market at the global level.

\footnotetext{
${ }^{10}$ Note however that capacity can be considered as a different product in energy market

${ }^{11}$ E.on has subsidiaries LG\&E and Powergen. Intergen is a group formed from equal participation of Shell and Bechtel. Tractabel Power belongs to the Suez Group.
} 
Table 2: Regional HHI for Electricity Generation (2003)

\begin{tabular}{|c|c|c|c|c|c|c|c|}
\hline & GLOBAL & Africa & $\begin{array}{c}\text { Asia \& } \\
\text { Oceania }\end{array}$ & $\begin{array}{c}\text { Latin } \\
\text { America }\end{array}$ & $\begin{array}{c}\text { North } \\
\text { America }\end{array}$ & $\begin{array}{l}\text { Eastern } \\
\text { Europe }\end{array}$ & $\begin{array}{l}\text { Western } \\
\text { Europe }\end{array}$ \\
\hline Market indicator & \multicolumn{7}{|c|}{ Installed Capacity per country (MW) } \\
\hline HH min & 734 & 592 & 594 & 1762 & 20 & 48 & 1386 \\
\hline HH max & 1630 & 1527 & 1261 & 3467 & 206 & 416 & 2893 \\
\hline $\begin{array}{l}\text { Aggregate market } \\
\text { share }\end{array}$ & $18 \%$ & $16 \%$ & $15 \%$ & $47 \%$ & $10 \%$ & $8 \%$ & $40 \%$ \\
\hline Number of firms & 16 & 5 & 10 & 10 & 9 & 7 & 12 \\
\hline $\begin{array}{l}\text { Number of } \\
\text { countries }\end{array}$ & 57 & 6 & 14 & 15 & 2 & 8 & 12 \\
\hline Cases & 157 & 7 & 29 & 60 & 12 & 13 & 36 \\
\hline Main actors & $\begin{array}{c}\text { AEP, AES, CLP, } \\
\text { Duke, E.ON, EDF, } \\
\text { EDP, ENDESA, } \\
\text { ENTERGY, UF, } \\
\text { HEG, Intergen, } \\
\text { PSEG, Reliant, } \\
\text { Southern, Tractabel }\end{array}$ & $\begin{array}{c}\text { AES, } \\
\text { EDF, } \\
\text { UF, } \\
\text { Intergen, } \\
\text { PSEG }\end{array}$ & $\begin{array}{c}\text { AES, } \\
\text { CLP, } \\
\text { Duke, } \\
\text { EON, EDF } \\
\text { HEG, UF, } \\
\text { Intergen, } \\
\text { PSEG, } \\
\text { Tractebel } \\
\end{array}$ & $\begin{array}{l}\text { AEP, AES, } \\
\text { Duke, EDF, } \\
\text { EDP, } \\
\text { ENDESA, } \\
\text { UF, Intergen, } \\
\text { PSEG, } \\
\text { Tractabel }\end{array}$ & $\begin{array}{c}\text { AEP, AES, } \\
\text { Duke, E.ON, } \\
\text { ENTERGY, } \\
\text { PSEG, } \\
\text { Reliant, } \\
\text { Southest, } \\
\text { Tractabel }\end{array}$ & $\begin{array}{c}\text { AES, } \\
\text { EDF, } \\
\text { Entergy } \\
\text { E.ON, } \\
\text { PSEG, } \\
\text { Tractebel, } \\
\text { UF }\end{array}$ & $\begin{array}{c}\text { AEP, AES, } \\
\text { Duke, E.ON, } \\
\text { EDF, EDP, } \\
\text { ENDESA, } \\
\text { UF, Intergen, } \\
\text { PSEG, } \\
\text { Reliant, } \\
\text { Tractabel } \\
\end{array}$ \\
\hline
\end{tabular}

At the regional level, a strict adherence to the rule suggested above would however only clear North America and Eastern Europe of any market power. Both Latin America and Western Europe should be sources of concern for an hypothetical supranational competition agency as indicated by the HHIs and hinted at by the large market shares of the operators present in the regions. For Western Europe, this is not a surprise since the liberalization of the sector has not yet fully been implemented. For Latin America, this comes as a major surprise. Indeed, Latin America is the region in which the largest number of countries have some significant reform levels in the sector. In over half of the countries of the region, the private sector now has a significant role in generation. Yet Table 2 suggests that even the lower bound of the HHI is close to what would justify a pro-active role for a supranational competition agency concerned with the degree of concentration in the sector.

\section{b. Electricity Distribution}

For distribution, we have data on 12 firms present in 31 countries (12 OECD and 19 non OECD). They account for $31 \%$ of the global electricity distribution market. We only have data on one of the two countries for North America and hence we do not deal with it at the regional level since the methodology would produce a country specific indicator. The sample size for some of the regions (Africa and Asia) is also rather small - to a large extent because of the few deals with private operators in this activity in both regions--and hence the results are likely to be biased and of lesser interest. The companies included are: American Electric Power, AES Corporation, CLP Group, E.ON, Electricité de France (EDF), Electricidade de 
Portugal (EDP), ENDESA, ENTERGY, Union Fenosa, Hong Kong Electric Group (HEG),

Public Service Enterprise Group (PSEG) and Southern Energy Company.

Table 3: Regional HHI for Electricity Distribution

\begin{tabular}{|c|c|c|c|c|c|c|c|}
\hline & GLOBAL & Africa & $\begin{array}{c}\text { Asia \& } \\
\text { Oceania }\end{array}$ & $\begin{array}{c}\text { Latin } \\
\text { America }\end{array}$ & $\begin{array}{c}\text { North } \\
\text { America }\end{array}$ & $\begin{array}{l}\text { Eastern } \\
\text { Europe }\end{array}$ & $\begin{array}{l}\text { Western } \\
\text { Europe }\end{array}$ \\
\hline Market indicator & \multicolumn{7}{|c|}{ Number of customers per country } \\
\hline HH min & 1498 & 663 & 1075 & 1433 & - & 2316 & 2000 \\
\hline $\begin{array}{l}\text { Aggregate market } \\
\text { share }\end{array}$ & $31 \%$ & $16 \%$ & $33 \%$ & $41 \%$ & $12 \%$ & $38 \%$ & $43 \%$ \\
\hline Cases & 51 & 3 & 4 & 20 & 5 & 6 & 13 \\
\hline Main actors & $\begin{array}{c}\text { AEP, AES, CLP, E.ON, } \\
\text { EDF, EDP, ENDESA, } \\
\text { ENTERGY, UF, HEG, } \\
\text { PSEG, Southeast }\end{array}$ & $\begin{array}{l}\text { AES, } \\
\text { EDF, } \\
\text { EDP }\end{array}$ & $\begin{array}{l}\text { CLP, UF, } \\
\text { HEG }\end{array}$ & $\begin{array}{l}\text { AES, EDF, } \\
\text { EDP, } \\
\text { ENDESA, } \\
\text { UF, PSEG }\end{array}$ & $\begin{array}{l}\text { AEP, AES, } \\
\text { E.ON, } \\
\text { ENTERGY, } \\
\text { Southest }\end{array}$ & $\begin{array}{l}\text { AES, } \\
\text { E.ON, } \\
\text { UF }\end{array}$ & $\begin{array}{l}\text { E.ON, EDF, } \\
\text { EDP, } \\
\text { ENDESA, UF }\end{array}$ \\
\hline
\end{tabular}

The decision rule proposed suggests that globally this sector is probably subject to a market power problem. EDF, Endesa and E.ON seem to be strong leaders at the global level with respectively $38.1 \%, 15.2 \%$ and $14.8 \%$ served by the 12 top operators of the business. Even if $\mathrm{HH}$ min does not reach the 1800 threshold, it is high enough to raise some concern. This impression is strongly enhanced by the HH max which is well above the threshold and this for a fairly large sample size. All of Europe is clearly a concern since in both Eastern and Western Europe, all of the HH are above the 1800 threshold. As mentioned earlier, the liberalization of the sector has not yet gone very far. In Eastern Europe, the issue is that few countries have actually privatized their distribution and E.ON enjoys a significant share of the market by itself. Latin America and Asia \& Oceania are both inconclusive but are in the range in which it may make sense to take a closer look at the situation. For Latin America, this is once more somewhat surprising. For all of its reforms, the dominating presence of Endesa, EDF and AES in several of the national markets of the region explain the high $\mathrm{HH}$ max.

\subsection{Telecoms}

The market indicator is the number of lines in working conditions controlled by an operator and the information is collected from the 2003 annual report of each firm. We consider fixed and mobile technologies separately. ${ }^{12}$ For each sub sector, we consider the 10

\footnotetext{
${ }^{12}$ Even if an obvious question in the "real world" would be to consider that the extent to which a product market that combines fixed and mobile should not also be considered since most of the top firms are the same in the two markets.
} 
first firms identified in a 1999 ITU report in a ranking of the main 20 providers according to their turnover. It turns out that 8 of these firms are present in both the fixed and the mobile lines business. For fixed lines, the 9 top firms were then: Bell South Corporation, BT Group, Deutsche Telekom, France Telecom, SBC, Telecom Italia, Telefonica de España, Telstra, and Verizon. For mobile, the firms covered are: Bell South Corporation, Deutsche Telekom, France Telecom, SBC, Telecom Italia, Telefonica de España, Telstra, Verizon and Vodafone. BT is dropped from the mobile list while Vodaphone is not present in the fixed line list. For fixed lines we consider 35 countries (18 OECD and 17 non OECD) while for mobile, we cover 65 countries (20 OECD and 45 non OECD).

A few words of caution on this list may be appropriate. First, there is a fair amount of turnover in ownership in this sector. Some of the firms in the 1999 list have now changed owners (and names). Our choice of operators is thus arbitrarily frozen in 1999 even if the information is collected for these companies in their form as of 2003. Second, there is a clear regional specialization of firms. There are only 4 firms with a strong presence in LDCs: France Telecom, SBC, Telecom Italia, Telefonica de España. This last one is particularly dominating in Latin America, Telstra in Asia and France Telecoms in Eastern Europe. Third, the list does not do justice to the growing presence of regional actors in the various regional markets with strong South African firms present in Africa and strong Mexican and Brazilian operators present in Latin America for instance. However, most of these firms and many of those included in the ITU list do not publish the necessary information on their webpages and hence we cannot make a fair assessment of their effective role in diluting or reinforcing market power in this sector. However, many of these firms are often at least partially owned and controlled by one of the top 12 through cross-ownership arrangements. Overall, the firms covered here are present in 67 countries through 127 operators.

\section{a. Telecoms Fixed}

With the market performance indicator adopted here and based on the 35 countries in which the top 9 operators are present, Table 4 shows that the global concentration level is quite high. These operators controlled 39\% of the market in 2003 and have both the HH min and HH max above the 1800 threshold level. This very high levels of concentration generally reported is not that surprising. In many countries, fixed telephony is still a monopoly. What is more surprising is to see the low ratio of firms to country across regions. Only Africa and 
North America would enjoy the benefit of the doubt under the decisions rule adopted here to decide the existence of a concentration problem. Latin America and Europe- both east and west - are once again the two regions in which the concentration levels are the highest. Eastern Europe and Asia are not that far behind.

While the concentration indicators are useful, once more, they do not tell the full story. First, it may be useful to point out that in 2003, Deutsche Telekom and SBC shared $40 \%$ of the market controlled by these 9 companies in the world. Second, actors relatively small at the global level can be very important are the regional level. This is the case of Telstra who is big in Asia but relatively small globally. Finally, however strong the presence of these firms may be in developing areas, for most of them the core business continues to be in developed countries, most importantly in Western Europe and North America.

Table 4: Regional HHI for Telecoms - Fixed

\begin{tabular}{|l|c|c|c|c|c|c|c|c|}
\hline & GLOBAL & Africa & $\begin{array}{c}\text { Asia \& } \\
\text { Oceania }\end{array}$ & $\begin{array}{c}\text { Latin } \\
\text { America }\end{array}$ & $\begin{array}{c}\text { North } \\
\text { America }\end{array}$ & $\begin{array}{c}\text { Eastern } \\
\text { Europe }\end{array}$ & $\begin{array}{c}\text { Western } \\
\text { Europe }\end{array}$ \\
\hline Market indicator & \multicolumn{7}{|c|}{ Number of working lines per country } \\
\hline HH min & $\mathbf{2 0 0 9}$ & 888 & 2265 & 2859 & 524 & 2075 & 3443 \\
\hline HH max & $\mathbf{3 5 5 1}$ & 2342 & 4169 & 3929 & 1796 & 4499 & 4570 \\
\hline Aggregate market share & $\mathbf{3 9 \%}$ & $23 \%$ & $42 \%$ & $46 \%$ & $30 \%$ & $45 \%$ & $48 \%$ \\
\hline Number of firms & $\mathbf{9}$ & 2 & 2 & 4 & 3 & 2 & 6 \\
\hline Number of countries & $\mathbf{3 5}$ & 6 & 4 & 9 & 2 & 3 & 11 \\
\hline Cases & $\mathbf{4 2}$ & 6 & 4 & 12 & 4 & 4 & 12 \\
\hline Main actors & $\begin{array}{c}\text { Bell South, BT, } \\
\text { Deutsche Telekom, } \\
\text { France Telecom, } \\
\text { SBC, Telecom Italia, } \\
\text { Telefonica de España, } \\
\text { Telstra, Verizon }\end{array}$ & $\begin{array}{c}\text { France } \\
\text { Telecom, }\end{array}$ & $\begin{array}{c}\text { SBC } \\
\text { Telecom, } \\
\text { Telstra }\end{array}$ & $\begin{array}{c}\text { SBC, } \\
\text { Telecom } \\
\text { Italia, } \\
\text { Telefonica } \\
\text { de España, } \\
\text { Verizon }\end{array}$ & $\begin{array}{c}\text { Bell South, } \\
\text { SBC, } \\
\text { Verizon }\end{array}$ & $\begin{array}{c}\text { Deutsche } \\
\text { Telekom, } \\
\text { France } \\
\text { Telecom }\end{array}$ & $\begin{array}{c}\text { BT, Deutsche } \\
\text { Telekom, France } \\
\text { Telecom, SBC, } \\
\text { Telecom Italia, } \\
\text { España }\end{array}$ \\
\hline
\end{tabular}

\section{b. Mobile Telecoms}

Globally, based on our sample of 65 countries in which the top 9 operators are present, the measure proposed here suggests that it is difficult to make an assessment of the degree of market power in the sector. The $\mathrm{HH}$ max is fairly high but the $\mathrm{HH}$ min is below the 1000 threshold level which makes the indicator inconclusive. The fact that 9 firms cater to $37 \%$ of the market seems to suggest a relatively large number of actors. But this does not tell the full story. Indeed, in 2003 Vodaphone controls 33\% of the number of working lines credited to these 9 companies. Telefonica de España, SBC and Verizon added up to a further $40 \%$ of that total. This suggests that at the global level, 4 actors are particularly important. 
Table 5 Regional HHI for Telecoms - Mobile

\begin{tabular}{|c|c|c|c|c|c|c|c|}
\hline & GLOBAL & Africa & $\begin{array}{c}\text { Asia \& } \\
\text { Oceania }\end{array}$ & $\begin{array}{c}\text { Latin } \\
\text { America }\end{array}$ & $\begin{array}{c}\text { North } \\
\text { America }\end{array}$ & $\begin{array}{l}\text { Eastern } \\
\text { Europe }\end{array}$ & $\begin{array}{l}\text { Western } \\
\text { Europe }\end{array}$ \\
\hline Market indicator & \multicolumn{7}{|c|}{ Number of working lines per country } \\
\hline HH min & 994 & 1113 & 655 & 1507 & 464 & 1000 & 1222 \\
\hline HH max & 2778 & 2748 & 1838 & 3576 & 2521 & 2584 & 3402 \\
\hline Aggregate market share & $37 \%$ & $31 \%$ & $22 \%$ & $48 \%$ & $36 \%$ & $38 \%$ & $50 \%$ \\
\hline Number of firms & 9 & 4 & 6 & 7 & 5 & 6 & 7 \\
\hline Number of countries & 65 & 10 & 13 & 16 & 2 & 9 & 15 \\
\hline Cases & 125 & 12 & 14 & 36 & 6 & 19 & 38 \\
\hline Main Actors & $\begin{array}{c}\text { Bell South, Deutsche } \\
\text { Telekom, France } \\
\text { Telecom, SBC, } \\
\text { Telecom Italia, } \\
\text { Telefonica de } \\
\text { España, Telstra, } \\
\text { Verizon and } \\
\text { Vodafone }\end{array}$ & $\begin{array}{c}\text { France } \\
\text { Telecom, } \\
\text { SBC, } \\
\text { Telefonica } \\
\text { de } \\
\text { España, } \\
\text { Vodafone }\end{array}$ & $\begin{array}{c}\text { Bell } \\
\text { South, } \\
\text { Deutsche } \\
\text { Telekom, } \\
\text { France } \\
\text { Telecom, } \\
\text { SBC, } \\
\text { Telstra, } \\
\text { Vodafone }\end{array}$ & $\begin{array}{c}\text { Bell South, } \\
\text { France } \\
\text { Telecom, } \\
\text { SBC, } \\
\text { Telecom } \\
\text { Italia, } \\
\text { Telefonica } \\
\text { de España, } \\
\text { Verizon, } \\
\text { Vodafone }\end{array}$ & $\begin{array}{l}\text { Bell South, } \\
\text { Deutsche } \\
\text { Telekom, } \\
\text { SBC, } \\
\text { Verizon } \\
\text { and } \\
\text { Vodafone }\end{array}$ & $\begin{array}{c}\text { Deutsche } \\
\text { Telekom, } \\
\text { France } \\
\text { Telecom, } \\
\text { SBC, } \\
\text { Telecom } \\
\text { Italia, } \\
\text { Verizon, } \\
\text { Vodafone }\end{array}$ & $\begin{array}{c}\text { Bell, South, } \\
\text { Deutsche } \\
\text { Telekom, } \\
\text { France } \\
\text { Telecom, } \\
\text { SBC, } \\
\text { Telecom } \\
\text { Italia, } \\
\text { Telefonica de } \\
\text { España, } \\
\text { Vodafone }\end{array}$ \\
\hline
\end{tabular}

Although the test are inconclusive at the regional level, in the case of Africa, Latin America and the two European Regions, the fact that the HH min is above the 1000 threshold suggests that a presumption of concentration could be argued by an hypothetical supranational competition agency. For North America and Asia \& Oceania, the presumption would go the other way around.

To get a fuller sense of the situation, it is useful to point out that like in the fixed line business, there is a regional specialization of the main actors. In 2003, Deutsche Telekom and Vodaphone were the major actors in Western Europe who together controlled 35\% of that regional market for the 9 leading companies of the world. They were followed at a distance by France Telecoms and Telefonica de España who add up to about 10\% of that market. Deutsche Telekom and Vodaphone were also very strong in North America, Eastern Europe, Asia \& Oceania. The developing world market is largely dominated by France Telecoms, Telefonica de España, Telecom Italia, SBC, Verizon and Vodaphone. These companies do seem to have regional specialization. Telefonica de España is, as in the case of fixed lines, the main player in Latin America but with a strong presence of Telecom Italia, SBC and Verizon. France Telecom is a leader in Eastern Europe (with Deutsche Telekom) and in Africa (with Vodaphone). 


\subsection{Water and Sanitation}

We consider the seven most important private firms that provided water and sanitation around the world in 2003. These companies are present in at least 61 countries. The set is made by: Ondeo, Veolia, RWE, Saur, United Utilities (UUT), Anglian Waters (AWG) and Severn Trent (SET). ${ }^{13}$ The information is provided by each firm in its annual report (2003) available from the web site of these companies or from the national stock market commission for listed companies. We also relied on information collected from the web site of the Public Services International Research Unit and by a 2003 report on the sector by Lehman Brothers. $^{14}$

The total information available is, per country and firm, the population coverage by water service and sewerage. In addition, there is a set of 19 more private firms present in these 62 countries. Typically, these are spin-offs of local construction companies. The water business is increasingly popular indeed in the construction sector in developing countries. Most of the Brazilian market for instance is catered to by Brazilian construction firms. The global information is however limited and we can only determine how many of these firms there are per country as well as the share of the total population they cover. We call this set as "Other Private Providers" (OPP). ${ }^{15}$ They represent about one third of the global market and their share in regional markets varies from less than 15\% in Eastern Europe to almost $60 \%$ in Latin America where all the local construction companies have become such big players in many countries that they control the largest market of the region (i.e. Brazil). Hall et al. (2004) for instance document the role of many Asian companies in Asia, alone or in partnerships with OECD companies (Veolia, Ondeo/Suez and Thames). From Hong Kong, Citic Pacific, NWS Holding, China Everbright and China Water are all active in the Chinese market. In Malaysia, Pucak Niaga, Ranhill Utilities and Taliworks Corp are three of the larger water and sanitation companies in the country. Other Malaysian companies such as Pilecon, PPB/Keery Utilities, PBA Holdings Berhad and Salcom are mostly active in China.

\footnotetext{
${ }^{13}$ Bechtel is probably the only major actor missing from this list but we did not have enough information to include it.

${ }^{14}$ Missing from the report are the British Biwater and the Dutch Ne-on who often team up as consortia during the 1990s in particular in East Asia.

${ }^{15}$ The information available on OPPs includes urban and country population covered by these OPPs in each country together with the number of these firms per country. Therefore, it is not possible to compute the market share of each OPP. However, to compute the $\mathrm{CRm}$, this information is not required since the aggregate market share and the number of the OPPs per country is enough.
} 
In our assessment of the concentration rates, we distinguish between water and sanitation. In water, we cover 56 countries (23 OECD and 33 non OECD) and in sanitation 38 countries (20 OECD and 18 non OECD). The market is defined in two ways. The first focuses on the share of urban population covered and serves as an upper bound for the degree of concentration. The second is the share of total population in each country and serves as a lower bound. The first may be a good approximation of the appropriate market in developing countries since large private firms tend to specialize in urban water systems. It may not be the right proxy for developed economies where full coverage has been achieved.

\section{a. Water}

Somewhat surprisingly given the large publicity given to the high degree of concentration of this market, the indicators for both urban and total population are inconclusive. The presumption from the $\mathrm{HH}$ generated by the urban indicator is however that concentration leaning towards strong at the global and regional level. In contrast, the presumption is not confirmed by the larger market definition since the $\mathrm{HH}$ max for the country population is below 1800 -although border line.

Table 6: Regional HHI - Water

\begin{tabular}{|c|c|c|c|c|c|c|c|}
\hline & GLOBAL & Africa & $\begin{array}{l}\text { Asia \& } \\
\text { Oceania }\end{array}$ & $\begin{array}{c}\text { Latin } \\
\text { America }\end{array}$ & $\begin{array}{c}\text { North } \\
\text { America }\end{array}$ & $\begin{array}{l}\text { Eastern } \\
\text { Europe }\end{array}$ & $\begin{array}{l}\text { Western } \\
\text { Europe }\end{array}$ \\
\hline Market indicator & \multicolumn{7}{|c|}{$\begin{array}{l}\text { 1. Urban population (upper bound concentration) } \\
\text { 2. Country population (lower bound concentration) }\end{array}$} \\
\hline HH min(urban) & 1163 & 2990 & 353 & 585 & 1598 & 809 & 643 \\
\hline HH max (urban) & 2857 & 4514 & 2174 & 1874 & 3467 & 2580 & 2536 \\
\hline HH min (country) & 514 & 648 & 120 & 263 & 1290 & 423 & 339 \\
\hline HH max (country) & 1694 & 2043 & 763 & 1291 & 2777 & 1586 & 1702 \\
\hline $\begin{array}{lll}\begin{array}{l}\text { Aggregate } \\
\text { (urban) }\end{array} & \text { market } & \text { share } \\
\end{array}$ & $34 \%$ & $49 \%$ & $25 \%$ & $28 \%$ & $40 \%$ & $31 \%$ & $31 \%$ \\
\hline $\begin{array}{lll}\begin{array}{l}\text { Aggregate } \\
\text { (country) }\end{array} & \text { market } & \text { share }\end{array}$ & $23 \%$ & $23 \%$ & $14 \%$ & $21 \%$ & $35 \%$ & $22 \%$ & $24 \%$ \\
\hline Number of firms & 7 & 4 & 6 & 5 & 5 & 5 & 7 \\
\hline Number of OPP & 19 & 7 & 7 & 16 & 10 & 8 & 16 \\
\hline Number of countries & 56 & 13 & 8 & 12 & 3 & 7 & 13 \\
\hline Cases & 151 & 18 & 29 & 35 & 14 & 12 & 43 \\
\hline Main actors & $\begin{array}{c}\text { AWG, RWE, } \\
\text { SAUR, SET, } \\
\text { ONDEO, } \\
\text { VEOLIA, UUT } \\
\text { and Others } \\
\text { Private Providers } \\
\text { (OPP) }\end{array}$ & $\begin{array}{c}\text { RWE, } \\
\text { SAUR, } \\
\text { ONDEO, } \\
\text { VEOLIA, } \\
\text { OPP }\end{array}$ & $\begin{array}{l}\text { AWG, } \\
\text { RWE, } \\
\text { SAUR, } \\
\text { ONDEO, } \\
\text { VEOLIA, } \\
\text { UUT, } \\
\text { OPP }\end{array}$ & $\begin{array}{c}\text { AWG, } \\
\text { RWE, } \\
\text { SAUR, } \\
\text { ONDEO, } \\
\text { VEOLIA, } \\
\text { OPP }\end{array}$ & $\begin{array}{c}\text { RWE, } \\
\text { ONDEO, } \\
\text { SET, } \\
\text { VEOLIA, } \\
\text { UUT, } \\
\text { OPP }\end{array}$ & $\begin{array}{c}\text { AWG, } \\
\text { RWE, } \\
\text { SAUR, } \\
\text { ONDEO, } \\
\text { VEOLIA, } \\
\text { OPP }\end{array}$ & $\begin{array}{c}\text { AWG, RWE, } \\
\text { SAUR, SET, } \\
\text { ONDEO, } \\
\text { UUT, } \\
\text { VEOLIA, } \\
\text { OPP }\end{array}$ \\
\hline
\end{tabular}

At the regional level, Africa is the only region where there is a clear concentration problem in terms of the urban population even if this is not confirmed by the indicator on the country population. The main actors are the three large French companies with the local 
private sector. The strong concentration is not surprising however in view of the marginal role played by large foreign operators in the rural parts of the country and in view of the fairly low level of coverage of network water suppliers in general in the region.

North America is the other region in which there may be some scope for concern. This region is in fact the only one in which the two indicators tell a consistency story. Note that it is important to remember that this data does not reflect the acceleration of the concentration process in this sector. As reported by D. Hall (2002), a series of recent takeovers of US companies by French companies is fueling this process. Suez bought US Water, which was owned by Bechtel and United Utilities, and also a number of Azurix contracts in Mexico. RWE-Thames have bought private water operations in the USA from Anglian Water.

For all of the other regions, there is no conclusive evidence of a major concentration problem based on either indicator. This is largely due to one of the most interesting story emerging in this sector. Indeed, in many countries, there is good evidence of a surprising large role of the local private water companies. Their role is the strongest in Latin America where they cater to the needs of roughly $58 \%$ of the population, followed closely by a share of $54 \%$ of North America's population. In Africa, Asia, Western Europe and Eastern Europe, they represent respectively $29 \%, 27 \%, 21 \%$ and $13 \%$ of the market. These figures help in keeping the HH indices low. They do not however reflect the fact that in Africa or Asia for instance, the main role of these local operators is to deliver the service where the large foreign private sector is not interested in view of the commercial risks they would face and the public sector has never been, or is no longer, able to deliver the services.

In terms of the overall market share of the various companies - defined in terms of the countries' population--, there is clear domination of the two large French companies, Ondeo and Veolia. When non global providers (OPPs) are taken into account, they control $43 \%$ of the market--when regional and national private players are ignored, they control two-thirds of the market. The next to large players are RWE and Saur with respectively $7.6 \%$ and $6.9 \%$ of the global market. The are the dominating actors in every regions except North America and Western Europe. 


\section{b. Sanitation}

In the sanitation sector, there is no clear case of concentration neither at the global level nor at the regional level. Although Ondeo and Veolia clearly dominate the market and are followed closely by the large German group RWE, there are other private operators (OPP). These OPP include many local players in many of the countries and serve about a third of the population of the world.

North America, is, once more, a clear border line under both types of market definition, suggesting that its sanitation market may be subject to some degree of market power by the few operators who dominate the market. The indicator is however formally inclusive. Eastern and Western Europe are also border cases when relying on the urban population indicator to define the market.

The developing regions of the world are much less concentrated than sometimes argued. This is largely due to the fact that coverage rates are fairly low. In many countries of the developing world, sanitation is a much less formal activity than in the developed part of the world.

Table 7: Regional HHI - Sanitation

\begin{tabular}{|c|c|c|c|c|c|c|c|}
\hline & GLOBAL & Africa & $\begin{array}{l}\text { Asia \& } \\
\text { Oceania }\end{array}$ & $\begin{array}{c}\text { Latin } \\
\text { America }\end{array}$ & $\begin{array}{c}\text { North } \\
\text { America }\end{array}$ & $\begin{array}{l}\text { Eastern } \\
\text { Europe }\end{array}$ & $\begin{array}{l}\text { Western } \\
\text { Europe }\end{array}$ \\
\hline Market indicator & \multicolumn{7}{|c|}{$\begin{array}{l}\text { 1. Urban population (upper bound concentration) } \\
\text { 2. Country population (lower bound concentration) }\end{array}$} \\
\hline HH min(urban) & 782 & 231 & 457 & 260 & 1738 & 1016 & 989 \\
\hline HH max (urban) & 2246 & 951 & 1063 & 1466 & 3504 & 3072 & 3416 \\
\hline HH min (country) & 476 & 51 & 156 & 171 & 1407 & 536 & 534 \\
\hline HH max (country) & 1542 & 452 & 565 & 1095 & 2837 & 1914 & 2391 \\
\hline Aggregate market share (urban) & $31 \%$ & $19 \%$ & $21 \%$ & $25 \%$ & $45 \%$ & $35 \%$ & $40 \%$ \\
\hline Aggregate market share (country) & $23 \%$ & $13 \%$ & $11 \%$ & $20 \%$ & $40 \%$ & $24 \%$ & $31 \%$ \\
\hline Number of firms & 7 & 2 & 1 & 12 & 5 & 5 & 7 \\
\hline Number of OPP & 19 & 7 & 0 & 0 & 7 & 13 & 13 \\
\hline Number of countries & 37 & 6 & 5 & 8 & 2 & 5 & 11 \\
\hline Cases & 102 & 9 & 15 & 27 & 12 & 2 & 37 \\
\hline Main actors & $\begin{array}{c}\text { AWG, RWE, } \\
\text { SAUR, SET, } \\
\text { ONDEO, } \\
\text { VEOLIA, } \\
\text { UUT and } \\
\text { Other Private } \\
\text { Providers } \\
\text { (OPP) }\end{array}$ & $\begin{array}{c}\text { ONDEO, } \\
\text { VEOLIA, } \\
\text { OPP, }\end{array}$ & $\begin{array}{c}\text { AWG, } \\
\text { RWE, } \\
\text { ONDEO, } \\
\text { UUT, } \\
\text { VEOLIA, } \\
\text { OPP }\end{array}$ & $\begin{array}{c}\text { AWG, } \\
\text { RWE, } \\
\text { SAUR, } \\
\text { ONDEO, } \\
\text { VEOLIA, } \\
\text { OPP }\end{array}$ & $\begin{array}{c}\text { RWE, } \\
\text { ONDEO, } \\
\text { SET, } \\
\text { VEOLIA, } \\
\text { UUT, } \\
\text { OPP }\end{array}$ & $\begin{array}{c}\text { AWG, } \\
\text { RWE, } \\
\text { SAUR, } \\
\text { ONDEO, } \\
\text { VEOLIA, } \\
\text { OPP }\end{array}$ & $\begin{array}{c}\text { AWG, } \\
\text { RWE, } \\
\text { SAUR, } \\
\text { SET, } \\
\text { ONDEO, } \\
\text { UUT, } \\
\text { VEOLIA, } \\
\text { OPP }\end{array}$ \\
\hline
\end{tabular}




\section{Policy implications}

In spite of the limitations stemming from the assumptions we had to make as a result of the poor quality of the information available and accounting for the very risk averse evaluation rule, this quantitative exercise provides a number of useful policy hints. Table 8 summarizes the information for each country grouping.

The first obvious conclusion is that there are very few certainties in general and no clear world wide sectoral pattern. There is no scope for simple encompassing regional or sectoral statements because issues are region- and sector-specific. The second is that at the Global level, the presumptions of concentration problems only arise for the businesses which use to be the main motivation to maintain these services in the public sector: electricity and water distribution as well as fixed phones services. Third, Western Europe is the region with the largest number of actual or potential concentration problems - it is in trouble in electricity and probably in telecoms as well. Eastern Europe follows closely with as many sectoral potentially problematic. North America, Africa and Asia \& Oceania have the fewest number of problematic sectors. Fourth, Eastern and Western Europe, Latin America and North America are the only regions with sector wide potential concentration problems. They are also among the most developed in the world - this list only exclude Oceania. This is somewhat surprising since these are also the regions in theory most committed to competition. Both telecoms business-fixed and mobile--have actual or potential problems in these regions sectors. Electricity-generation and distribution--is equivalently problematic in Western Europe and Latin America. Water and sanitation are an actual and a potential problem in North America. Fifth, the telecoms sector is overall the sector with the largest number of potential or actual concentration problems which is also a surprise in view of the widespread sense that the technological revolution made the sector competitive sooner and faster than any other sector. It may be less surprising considering the widespread difficulties in ensuring the design and enforcement of fair access rules in a business in which interconnection is at the core of everything. Sixth, from the viewpoint of one of the poorest regions of the world, it is unfortunate to see that one of the most concentrated sectors is the water sector in Africa in spite of the potential strong role of alternative operators in the region. ${ }^{16}$

\footnotetext{
${ }^{16}$ See Kariuki, M. and J. Schwartz (2004) for more on small scale operators in water and energy
} 
Table 8: Concentration Problems Diagnostic

\begin{tabular}{|c|c|c|c|c|c|c|}
\hline & \multicolumn{2}{|c|}{ Electricity } & \multicolumn{2}{|c|}{ Telecoms } & \multicolumn{2}{|c|}{ Water \& Sanitation } \\
\hline & Generation & Distribution & Fixed & Mobile & Water & Sanitation \\
\hline Global & $\begin{array}{c}\text { Inconclusive } \\
\text { towards No }\end{array}$ & $\begin{array}{l}\text { Inconclusive } \\
\text { towards Yes }\end{array}$ & $\begin{array}{l}\text { Inconclusive } \\
\text { towards Yes }\end{array}$ & $\begin{array}{l}\text { Inconclusive } \\
\text { towards No }\end{array}$ & $\begin{array}{l}\text { Inconclusive } \\
\text { towards Yes }\end{array}$ & $\begin{array}{c}\text { Inconclusive } \\
\text { towards No }\end{array}$ \\
\hline Africa & $\begin{array}{l}\text { Inconclusive } \\
\text { towards No }\end{array}$ & $\begin{array}{l}\text { Inconclusive } \\
\text { towards No }\end{array}$ & $\begin{array}{l}\text { Inconclusive } \\
\text { towards No }\end{array}$ & $\begin{array}{l}\text { Inconclusive } \\
\text { towards Yes }\end{array}$ & Yes & $\begin{array}{l}\text { Inconclusive } \\
\text { towards No }\end{array}$ \\
\hline Asia \& Oceania & $\begin{array}{l}\text { Inconclusive } \\
\text { towards No }\end{array}$ & $\begin{array}{l}\text { Inconclusive } \\
\text { towards Yes }\end{array}$ & $\begin{array}{l}\text { Inconclusive } \\
\text { towards Yes }\end{array}$ & $\begin{array}{l}\text { Inconclusive } \\
\text { towards No }\end{array}$ & $\begin{array}{l}\text { Inconclusive } \\
\text { towards No }\end{array}$ & $\begin{array}{l}\text { Inconclusive } \\
\text { towards No }\end{array}$ \\
\hline Latin America & Yes & $\begin{array}{l}\text { Inconclusive } \\
\text { towards Yes }\end{array}$ & Yes & $\begin{array}{l}\text { Inconclusive } \\
\text { towards Yes }\end{array}$ & $\begin{array}{c}\text { Inconclusive } \\
\text { towards No }\end{array}$ & $\begin{array}{l}\text { Inconclusive } \\
\text { towards No }\end{array}$ \\
\hline North America & No & - & $\begin{array}{l}\text { Inconclusive } \\
\text { towards No }\end{array}$ & $\begin{array}{l}\text { Inconclusive } \\
\text { towards No }\end{array}$ & Yes & $\begin{array}{l}\text { Inconclusive } \\
\text { towards Yes }\end{array}$ \\
\hline Eastern Europe & No & Yes & Yes & $\begin{array}{l}\text { Inconclusive } \\
\text { towards Yes }\end{array}$ & $\begin{array}{l}\text { Inconclusive } \\
\text { towards No }\end{array}$ & $\begin{array}{l}\text { Inconclusive } \\
\text { towards Yes }\end{array}$ \\
\hline $\begin{array}{l}\text { Western } \\
\text { Europe }\end{array}$ & Yes & Yes & Yes & $\begin{array}{l}\text { Inconclusive } \\
\text { towards Yes }\end{array}$ & $\begin{array}{l}\text { Inconclusive } \\
\text { towards No }\end{array}$ & $\begin{array}{l}\text { Inconclusive } \\
\text { towards Yes }\end{array}$ \\
\hline
\end{tabular}

\section{Concluding comments}

The paper has argued that since concentration in infrastructure markets can be associated situations resulting from anti-competitive behavior managed at the supranational level - collusion, predation, etc., it makes sense however to get a sense of the risks involved. The main focus of the research has been on the assessment the actual degree of concentration rather than on specific evidence of anticompetitive behavior. The paper has provided evidence of the complexity of the market structure of the main infrastructure services. Not a single sector is problematic across the board, implying that region specific conditions are the main determinants of the market structure observed in each region rather than the world or region wide supply side of the market alone. ${ }^{17}$

Although clear concentration issues were identified in only about $20 \%$ of the cases studied, a presumption of concentration was found in another $30 \%$ of the cases. Many of these perceived cases could be more problematic than suggested by the approximation adopted here. This is because the method largely ignored some important features of the sector which would reinforce the perception of concentration and of risks of collusion. Indeed, crossownership is increasingly common in this sector and generally underestimated by analysts. ${ }^{18}$

\footnotetext{
${ }^{17}$ The ideal would have been to try to track down the evolution of concentration since the reform but the data was simply not available.

${ }^{18}$ An exception is Campos and Vegas (2003) for the impact in Spain.
} 
The approach followed here does not do full justice to the consequences of this practice either. The fact that we have not been able to model this feature suggests that our assessment is a lower bound of the degree of concentration.

A second reason why this approach may be underestimating concentration is that it does not deal with many of the restrictions to entry (and exit) associated with the contractual arrangements characteristic of this sector. Indeed, there is not only a risk of collective dominance of the various actors as a result of the relatively narrow market structure, there is also the fact that by design many of the sectors are protected from competition by long term contracts signed with governments.

It is important to also recognize that the evidence on concentration provided here is not evidence of misbehavior. It would indeed be important to complement this paper with an explicit assessment of the association of concentration with negative performance outcomes since the linkage between the two is not automatic. Similarly, it would be desirable to track the evolution of concentration over time to monitor the direction of the evolution. The snapshot provided here does not say if things are improving or deteriorating.

For those cases in which concentration could be linked to undesirable outcomes, the main issue will be to develop a cross-border institutional solution which has the leverage and mandate to address issues national regulators are neither capable nor mandated to do. There is a growing literature on the options available to organize a supranational agency and this papers contributes empirical evidence on the policy relevance of this literature. Most of that literature however focuses on cross-border mergers and hardly addresses the issues of relevance to this sector and its many unusual idiosyncrasies.

This paper is clearly a first quantitative look at the issues. The definition of product markets assessed here was somewhat arbitrary. In view of the fact that the main actors are the same in mobile and fixed telephony or in water and in sanitation, it makes sense to also consider more encompassing product markets. But this is not the only direction to be considered. Indeed, in view of the cream skimming observed in many regions, there is some concern that different operators specialize in urban and rural service delivery. This implies that an additional line of empirical assessment would have to unbundle the sectors into these two types of product markets instead. 


\section{Appendix}

The main purpose is to control for ownership at the supranational level rather than for the traditional focus on market power at the national level. To do so, independently of whether a firm, $\mathrm{F}_{\mathrm{i}}$, in the sample has the control or not, we start with the share of each firm $i$ over the local providers, $\mathrm{LP}_{\mathrm{j}}$ of each country. To see this more clearly, consider countries $a$ and $b$ in which there are two local providers denoted by $L P_{1}$ and $L P_{2}$. The following table shows per country and local provider, the amount of certain variables i.e. MWs, customers, lines, urban or country population.

\begin{tabular}{lrrr} 
& \multicolumn{2}{c}{ Local Provider } & \multicolumn{2}{c}{ Market } \\
& LP1 & LP2 & \multicolumn{2}{c}{ Total } \\
Country a & 10 & 20 & 30 \\
Country b & 15 & 5 & 20
\end{tabular}

Suppose that in the sample there are two firms denoted by $F_{1}$ and $F_{2}$. They have the following shares in each local provider:

\begin{tabular}{lcrrr} 
& \multicolumn{2}{c}{$\boldsymbol{F}_{1}$ 's shares $(\%)$} & \multicolumn{2}{c}{$\boldsymbol{F}_{2}$ 's shares $(\%)$} \\
& $L P_{1}$ & $L P_{2}$ & $L P_{1}$ & $L P_{2}$ \\
Country a & $30 \%$ & $25 \%$ & $60 \%$ & $50 \%$ \\
Country b & $40 \%$ & $20 \%$ & $20 \%$ & $60 \%$
\end{tabular}

In this case, they own (weighted by the share) the following units:

\begin{tabular}{|c|c|c|c|c|}
\hline & \multicolumn{2}{|c|}{$F_{1}$} & \multicolumn{2}{|c|}{$F_{2}$} \\
\hline & $L P_{1}$ & $L P_{2}$ & $L P_{1}$ & $L P_{2}$ \\
\hline Country a & 3 & 5 & 6 & 10 \\
\hline Country b & 6 & 1 & 3 & 3 \\
\hline
\end{tabular}

And the concentration index is computed as:

$\begin{array}{lccrrr} & \mathbf{s}_{\mathbf{1}} & \mathbf{s}_{\mathbf{2}} & \mathbf{C R}_{\mathbf{m}} & \text { HHmin } & \text { HHmax } \\ \text { Country a } & 0.27 & 0.53 & 0.80 & 3200 & 6400 \\ \text { Country b } & 0.35 & 0.30 & 0.65 & 2113 & 4225 \\ \text { Region } & & & & 2656 & 5313\end{array}$

Formally, let's denote by $x_{i j}$ the amount of, for instance, MWs, customers or lines hold in country $i$ by some local firm $j$. Let's consider one firm of the sample, to say, firm $l$. If firm $l$ has $\alpha_{i, j}^{l}$ shares in firm $j$ in country $i$, then we argue that firm $l$ is the owner of $X_{i}^{l}=\sum_{j \in R(i, j)} \alpha_{i j}^{l} x_{i, j}$ units in country $i$ where $R(i, j)$ is a relation between firms and countries. The 
market share of firm $l$ is computed as $s_{i}^{l}=X_{i, j}^{l} / \sum_{j \in R(i, j)} x_{i, j}$ and the $m$ seller concentration ratio in country $i$ is $C R_{m}^{i}=\sum_{l \in G(i, l)} s_{i}^{l}$ where $m$ represent the set of firms $l$ that have activity in country $i$ and $G(i, l)$ is a relation between firms $l$ and countries $i$. Using this value, we compute $\mathrm{HH}_{\min }$ and $\mathrm{HH}_{\max }$ per country. Regional and Global concentration index are just the country average concentration index. 


\section{References}

Campos, J. and G. Vega (2003), "Concentration measurement under cross-ownership. An application to the Spanish electricity sector", Journal of Industry, Competition and Trade 3 (4): 313-335, December

Estache, A. (2003), "La régulation des services publics dans les PVD: mythes et réalités", paper presented at the Jules Dupuit Lectures, Paris, March

Estache, A. and L. Trujillo (2004), "La Privatización en América Latina en la Década de los Anos 90: Aciertos y Errores", Revista Asturiana de Economía, No31, pp37-59

Estache, A. And A. Goicoechea (2004), How really big were private investment and regulatory reform in infrastructure during the 1990s?", mimeo, The World Bank

European Commission, Commission Notice on remedies acceptable under Council Regulation (EEC), No 4064/89 and under Commission Regulation (EC) No447/98, IJ 2001 $\mathrm{C} 68 / 3,266$

Hall, D. (2002), "The water multinationals: financial and other problems", Public Services International Research Unit, available at www.pisru.org

Hall, D., V. Corral, E. Lobina and R. de la Motte (2004), "Water privatization and restructuring in Asia-Pacific", Public Services International Research Unit, available at www.pisru.org

International Energy Agency (2002), Global Energy Investment Prospects, Paris

International Telecommunication Union (ITU) database on total number of fixed and mobile lines per country (2001). http://www.itu.int

Kariuki, M. and J. Schwartz (2004), "Small-Scale Private Service Providers of Water Supply and Electricity: A Review of Incidence, Structure, Pricing and Operating Characteristics", mimeo, The World Bank

Lehman Brothers (2002), The Global Water Industry, http://www.lehman.com

Martin, S. (1993 ), Advanced Industrial Economics, Blackwell Publishers

Pepall, L. D.J. Richards and G. Norman (2002), Industrial Organization: Contemporary Theory and Practice, $2^{\text {nd }}$ edition, South-Western

Public Services International Research Unit, http://www.psiru.org

Sleuwaegen, L. and W. Dehandschutter (1986), "The critical choice between the concentration ratio and the H-index in assessing industry performance", Journal of Industrial Economics, 35(2), December, 193-208

US Department of Energy (2001), World Installed Energy Capacity, http://www.energy.gov.

US Department of Justice and Federal Trade Commission (1992), Horizontal Merger Guidelines 